\title{
PENGEMBANGAN PERANGKAT PEMBELAJARAN BIOLOGI BERBAHASA INGGRIS DENGAN PENDEKATAN KETERAMPILAN PROSES PADA MATERI KINGDOM JAMUR
}

\author{
Medina Andini' ${ }^{1)}$, Mohamad Nur ${ }^{2)}$, Yuni Sri Rahayu ${ }^{3)}$ \\ ${ }^{1)}$ Mahasiswa Program Studi Pendidikan Dasar, Program Pascasarjana Universitas Negeri Surabaya \\ ${ }^{2), 3)}$ Dosen Pascasarjana Prodi Pendidikan Sains Univesrtitas Negeri Surabaya \\ E-mail: ayanadewi@gmail.com
}

\begin{abstract}
The purpose of this research is to develop biology - Fungi Kingdom learning material in English with process skill approach that applied in 10th grade students in Khadijah Senior High School. The development of this learning materials was conducted by using 4-D model that has 4 main stages. However, this research only carried out 3 out 4 stages which are define, design, and develop. Meanwhile the last stage, disseminate, was not carried out in this research. This research used one group pretest-posttest design with quantitative-descriptive analytical technique and using qualitative-descriptive analytical technique. The validation results of the learning materials: syllabus, lesson plan, worksheet, learning media, and assessments, are in very valid category. The average achievement of product learning objectives is $84 \%$, the average achievement of process learning objectives in scientific drawing is $92 \%$, the average achievement of integrated process skill learning objectives is $94 \%$, the category achievement of presentation process learning objectives is 4,28 or the percentage is $85,6 \%$, and the average achievement psychomotor objective is $100 \%$. The class achievement for product assessment is $94,29 \%$, class achievement for process assessment in scientific drawing is $100 \%, 88,57 \%$ for class achievement for integrated process skill, psychomotor assessment is $100 \%$, and the average class achievement for presentation is 4,28 that shows good category. The students responds shows that 95\% of the students like the component of the learning materials, 93,33\% students state that the component of the learning materials are new, and $100 \%$ students like to learn using the learning materials. The student activities that dominate is the activity that focused on students, which are; the first meeting was observe the fungi structure, meanwhile in the second meeting the activity that dominate the learning process was discussion with the group, and in the third meeting the dominating activity was search in the internet. Based on the data obtained in this research, the learning materials that are developed are able to be used in learning activity.
\end{abstract}

Keywords: Biology Lesson In English, Science Process Skill Approach, Fungi Kingdom

Abstrak: Penelitian ini bertujuan untuk mengembangkan perangkat pembelajaran biologi berbahasa Inggris dengan pendekatan keterampilan proses sains pada materi Kingdom Jamur yang diujicobakan di kelas X SMA Khadijah Surabaya. Pengembangan perangkat pembelajaran dilakukan dengan menggunakan model 4-D yang terdiri atas 4 tahapan. Pada penelitian ini tahapan yang dilakukan hanya meliputi 3 tahapan awal yaitu define, design, dan develop, sedangkan tahap disseminate tidak dilakukan. Desain uji coba ini menggunakan one group pretest-posttest design dengan teknik analisis deskriptif kuantitatif dan deskriptif kualitatif. Hasil penelitian menunjukkan bahwa hasil validasi perangkat pembelajaran yang dikembangkan yaitu Silabus, RPP, Buku Siswa, LKS, Media Pembelajaran, dan Lembar Penilaian, berkategori sangat layak/valid. Rata-rata ketuntasan tujuan pembelajaran produk adalah $84 \%$, tujuan pembelajaran proses menggambar ilmiah memiliki rata-rata ketuntasan $92 \%$, dan ketuntasan tujuan pembelajaran proses terpadu adalah $94 \%$, rata-rata ketuntasan tujuan pembelajaran proses presentasi adalah 4,28 atau sebesar 85,6\% dengan kategori baik, dan ketuntasan tujuan pembelajaran psikomotor adalah 100\%. Ketuntasan klasikal adalah 94,29\% penilaian produk, $100 \%$ untuk penilaian proses menggambar ilmiah, 88,57\% untuk penilaian proses terpadu, $100 \%$ untuk penilaian psikomotor, dan rata-rata nilai siswa untuk penilaian proses presentasi adalah 4,28 dengan kategori baik. Respon siswa menunjukkan bahwa 95\% siswa menyukai komponen perangkat pembelajaran yang dikembangkan, 93,33\% menyatakan bahwa komponen perangkat pembelajaran yang dikembangkan adalah hal baru, dan $100 \%$ siswa menyatakan bahwa mereka menyukai pembelajaran dengan menggunakan perangkat pembelajaran yang dikembangkan. Aktivitas siswa yang paling dominan adalah aktivitas yang berpusat pada siswa, diantaranya adalah pada pertemuan pertama adalah mengamati struktur tubuh jamur, sedangkan pada pertemuan kedua aktivitas yang paling dominan adalah berdiskusi kelompok, dan pada pertemuan ke tiga, aktivitas yang paling dominan adalah melakukan searching internet. Berdasarkan data yang diperoleh dapat disimpulkan bahwa perangkat pembelajaran yang dikembangkan layak untuk digunakan dalam pembelajaran.

Kata kunci: Pembelajaran Biologi Berbahasa Inggris, Pendekatan Keterampilan Proses, Kingdom Jamur

Model Pembelajaran Pemaknaan pada Materi Sistem 


\section{PENDAHULUAN}

Biologi sebagai salah satu bidang IPA menyediakan berbagai pengalaman belajar untuk memahami konsep dan proses sains. Proses atau yang biasa disebut dengan keterampilan proses sains ini meliputi keterampilan mengamati, merumuskan masalah, mengajukan hipotesis, menggunakan alat dan bahan secara baik dan benar dengan selalu mempertimbangkan keamanan dan keselamatan kerja, mengajukan pertanyaan, menggolongkan dan menafsirkan data, menganalisis data, membuat kesimpulan, serta mengkomunikasikan hasil temuan secara lisan atau tertulis, menggali dan memilah informasi faktual yang relevan untuk menguji gagasangagasan atau memecahkan masalah sehari-hari.

Keterampilan proses sains melibatkan keterampilan-keterampilan kognitif atau intelektual, manual, dan sosial. Dengan mengembangkan keterampilan proses, peserta didik akan mampu menemukan dan mengembangkan sendiri fakta dan konsep serta menumbuhkan dan mengembangkan sikap dan nilai yang dituntut.

Penguasaan keterampilan proses siswa yang masih rendah dapat diamati dari hasil tes keterampilan proses yang diberikan pada siswa juga dari hasil observasi yang dilakukan peneliti terhadap naskah ujian nasional menunjukkan bahwa keterampilan proses bukanlah komponen utama yang diujikan, hal ini mengakibatkan pembelajaran dengan pendekatan keterampilan proses di sekolah jarang sekali diterapkan sehingga siswa belum sepenuhnya menguasai keterampilan proses. Dari hasil observasi tersebut, maka untuk dapat meningkatkan berbagai keterampilan proses sains perlu adanya pengembangan perangkat pembelajaran yang dapat mengembangkan keterampilan proses sains dari peserta didik.

Sebagaimana yang diungkapkan oleh Pramita (2013) bahwa penyelenggaraan RSBI dilandasi oleh beberapa alasan, diantaranya adalah era globalisasi yang menuntut kemampuan daya saing yang kuat dalam teknologi manajemen dan sumber daya manusia, adanya dasar hukum yang kuat, dan penyelenggaraan yang didasari oleh filosofi eksistensialisme dan sensialisme (fungsionalisme).

Terkait dengan beberapa kekurangan dan kelebihan dari sekolah RSBI yang mengakibatkan adanya ketimpangan dalam beberapa hal, pemerintah memutuskan untuk menghapus program RSBI. Pada awal tahun 2013 dan menerapkan kurikulum baru yaitu Kurikulum 2013 yang memiliki tujuan utama membangun sisi kemampuan berpikir anak-anak secara ilmiah. Sehingga keterampilan proses sains merupakan pendekatan yang tepat untuk digunakan baik untuk sekolah RSBI maupun untuk Kurikulum 2013.

Anglo (2002) menyatakan bahwa pengalaman siswa sekolah dalam pembelajaran terbimbing seharusnya melibatkan pengalaman yang meningkatkan keterampilan proses karena keterampilan tersebut sangat penting untuk pengembangan pemahaman siswa yang utuh dan berhasil terhadap konsep dan hukum sains.

\section{METODE PENELITIAN}

\section{A. Subyek Penelitian}

Subyek penelitian adalah perangkat pembelajaran biologi berbahasa Inggris dengan pendekatan keterampilan proses pada materi Kingdom Jamur yang telah dikembangkan. Subyek uji coba adalah siswa kelas X SMA Khadijah Surabaya sebanyak 35 siswa pada bulan Juli 2012 pada tahun ajaran 2012/2013.

\section{B. Desain Uji Coba}

Desain penelitian pada uji coba menggunakan preeksperimen design dengan One Group Pre Test and Post Test Design dengan menggunakan rancangan penelitian sebagai berikut (Tuckman, 1978):

\section{$01 \times 02$}

Dimana:

O1 : Pemberian uji awal (pre test).

O2 : Pemberian uji akhir (post test).

$\mathrm{X}$ : Perlakuan pembelajaran biologi berorientasi model pembelajaran berbasis portofolio

\section{Prosedur Penelitian}

Prosedur penelitian ini terdiri atas 2 tahap, yakni tahap I merupakan tahap pengembangan perangkat pembelajaran, dan tahap II merupakan tahap uji coba/implementasi perangkat pembelajaran.

Pola yang digunakan untuk merancang pengembangan perangkat pembelajaran ini mengacu pada The Four $D$ model yang dikembangkan oleh Thiagarajaan dan Semmel (1974) terdiri dari empat tahap yaitu pendefinisian (Define), perancangan (Design), pengembangan (Develop) dan penyebaran (Disseminate) yang dimodifikasi oleh peneliti sesuai kebutuhan di lapangan. Penelitian yang dilakukan hanya sampai pada tahap Develop.

Fase pengembangan perangkat: aktivitas yang dilakukan dalam fase pengembangan ini adalah membuat perangkat pembelajaran dan instrumen penelitian. Perangkat pembelajaran meliputi Silabus, Rencana Pelaksanaan Pembelajaran (RPP) yang dibagi dalam 3 pertemuan dimana pertemuan 1 dan 2 dengan menggunakan model pembelajaran langsung, sedangkan 3 dengan menggunakan model pembelajaran kooperatif, Buku Siswa, Lembar Kerja Siswa (LKS), media pembelajaran (PPT), dan Lembar Penilaian. Instrumen penelitian meliputi Lembar Validasi Perangkat, Lembar Penilaian Hasil Pembelajaran, Angket Respon Siswa, Lembar Pengamatan 
Keterlaksanaan RPP, Lembar Pengamatan Aktivitas Siswa, Lembar Pengamatan Kendala/Hambatan di Lapangan.

Fase Implementasi pembelajaran: implementasi perangkat pembelajaran meliputi keterlaksanaan rencana pelaksanaan pembelajaran di kelas untuk mengetahui efektivitas keterlaksanaan perangkat pembelajaran dan efektivitas penerapan perangkat pembelajaran biologi berbahasa Inggris dengan pendekatan keterampilan proses pada materi Kingdom Jamur yang dikembangkan.

\section{Tehnik Pengumpulan Data}

Tehnik pengumpulan data penelitian ini dilakukan dengan beberapa cara, yaitu validasi perangkat pembelajaran, pengamatan (observasi), angket, dan tes. Validasi dilakukan terhadap perangkat pembelajaran yang dikembangkan, sedangkan observasi dilakukan untuk mendapatkan data keterlaksanaan RPP, aktivitas siswa, kendala-kendala di lapangan. Angket digunakan untuk mengetahui respon siswa dalam mengikuti kegiatan pembelajaran dengan perangkat yang telah dikembangkan. Tes dilakukan untuk mengukur hasil belajar produk, proses, psikomotor, dan afektif.

\section{E. Tehnik Analisis Data}

Data hasil penelitian di analisis secara deskriptif kualitatif dan analisis kuantitatif. Adapun data yang dianalisis meliputi validasi perangkat pembelajaran dan efektivitas penerapan perangkat pembelajaran biologi berbahasa Inggris dengan pendekatan keterampilan proses pada materi Kingdom Jamur yang dikembangkan, didasarkan pada hasil belajar siswa, keterlaksanaan rencana pelaksanaan pembelajaran (RPP), respon siswa selama mengikuti kegiatan pembelajaran, aktivitas siswa selama kegiatan pembelajaran, kendala/hambatan dalam menerapkan perangkat pembelajaran yang dikembangkan.

Data kelayakan perangkat dianalisis atas rata-rata skor penilaian tiga orang validator meliputi isi perangkat pembelajaran. Hasil belajar siswa yang akan dianalisis pada penelitian ini adalah hasil belajar produk, proses, psikomotor, dan afektif. Hasil belajar tersebut dinilai dari ketuntasan tujuan pembelajaran, ketuntasan individual, dan ketuntasan klasikal. Data dari keterlaksanaan rencana pelaksanaan pembelajaran dan aktivitas siswa dianalisis dari rata-rata skor penilaian dari dua orang pengamat.

\section{HASIL PENELITIAN DAN DISKUSI}

Analisis terhadap hasil penelitian pengembangan dan uji coba perangkat pembelajaran, dikemukakan dalam pembahasan berikut.
A. Validitas Perangkat Pembelajaran.

Skor rata-rata hasil validasi silabus yang dikembangkan adalah 4,58 dengan kategori sangat layak/valid dan reliabilitasnya adalah 90\%. Hasil validasi RPP memperlihatkan bahwa pada semua aspek mendapatkan skor dengan kategori sangat layak/valid, yaitu dengan rata-rata validasi RPP sebesar 4,30 dan reliabilitasnya adalah $88,89 \%$. Hasil validasi buku siswa memperlihatkan bahwa skor rata-rata hasil validasi buku siswa yang dikembangkan adalah 4,52 dengan kategori sangat layak/valid dan reliabilitasnya adalah $97,30 \%$. LKS yang dikembangkan oleh peneliti untuk menunjang buku siswa mendapatkan hasil validasi dengan skor rata-rata 4,62 dengan kategori sangat layak/valid dan reliabilitasnya adalah $100 \%$. Hasil Validasi Media Pembelajaran berupa PPT memperlihatkan skor rata-rata 4,50 dengan kategori sangat layak/valid dan reliabilitasnya adalah $96,76 \%$. Hasil Validasi Lembar Penilaian yang terdiri atas Penilaian Produk dan Penilaian Proses mendapatkan hasil validasi dengan skor rata-rata 4,53 dengan kategori sangat layak/valid dan reliabilitasnya adalah $90,83 \%$.

Hasil validasi perangkat pembelajaran yang meliputi Silabus, Rencana Pelaksanaan Pembelajaran (RPP), Buku Siswa, LKS, Media Pembelajaran berupa Power Point Presentation (PPT), dan Lembar Penilaian (LP) mendapatkan penilaian dengan rentang 4,00-5,00 dengan kategori sangat layak/valid.

Penggunaan model pengembangan perangkat 4-D yang disarankan oleh Thiagarajan berperan besar dalam tercapainya kategori sangat layak/valid dalam pengembangan perangkat tersebut. Penggunaan model dengan empat tahap pengembangan yang sistematis ini sesuai dengan pola pikir peneliti dan memudahkan peneliti dalam membuat perangkat pembelajaran yang akan dikembangkan.

\section{B. Efektivitas Penerapan Perangkat Pembelajaran \\ 1. Hasil Belajar Siswa}

Menurut Hasanah (2012), ketuntasan hasil belajar siswa digunakan untuk mengetahui tingkat penguasaan siswa terhadap materi pembelajaran yang telah diberikan. Dari hasil belajar yang diperoleh siswa dapat diketahui efektifitas dari perangkat pembelajaran yang telah dikembangkan.

a. Ketuntasan Tujuan Pembelajaran

1) Tujuan Pembelajaran Produk

Dari hasil Pretest rata-rata ketuntasan tujuan pembelajaran produknya adalah $28 \%$. Ketuntasan tujuan pembelajaran produk ini mengingkat secara signifikan pada Posttest dengan rata-rata ketuntasan tujuan pembelajaran produk siswa sebesar $84 \%$.

Dari hasil pretest dan posttest tersebut dapat diketahui bahwa pengalaman belajar yang dialami oleh 
siswa akan sangat berpengaruh pada pencapaian tujuan pembelajaran. Hal ini tentunya tidak lepas dari RPP yang dikembangkan oleh peneliti selaku pengajar yang harus menyesuaikan karakter materi dan tujuan pembelajaran yang akan diajarkan dengan model pembelajaran yang akan digunakan.

2) Tujuan Pembelajaran Proses

Untuk tujuan pembelajaran proses 1 mengenai menggambar ilmiah dari hasil Pretest diketahu rata-rata ketuntasan tujuan pembelajaran proses 1 adalah $6 \%$ sedangkan hasil rata-rata Posttest untuk ketuntasan tujuan pembelajaran proses 1 mengenai menggambar ilmiah, rata-rata ketuntasannya adalah $92 \%$.

Sedangkan tujuan pembelajaran proses 2 mengenai Keterampilan Proses Sains terpadu mendapatkan hasil rata-rata Pretest sebesar $44 \%$ dan $84 \%$ pada Posttest.

Sebagaimana tujuan pembelajaran proses 1 , pada tujuan pembelajaran proses $2, \geq 75 \%$ siswa dapat menuntaskannya. Hal ini menunjukkan bahwa tujuan pembelajaran proses 2 dapat dituntaskan oleh siswa. Adapun komponenen tujuan pembelajaran proses 2 yang tidak dapat dituntaskan adalah dalam hal mengidentifikasi variabel, dimana hanya dapat dituntaskan oleh 6\% dari 35 siswa. Menurut peneliti hal ini disebabkan karena kurang terbiasanya siswa mendefinisikan sesuatu, termasuk mendefinisikan variabel dalam penelitian.

Dalam hal keterampilan proses dalam presentasi rata-rata skornya adalah $4,28 \%$. Dari hasil tersebut dapat diketahui bahwa pengalaman belajar yang dialami oleh siswa akan sangat berpengaruh pada pencapaian tujuan pembelajaran baik tujuan pembelajaran produk sebagaimana telah dijabarkan di atas dan tujuan pembelajaran proses.

3) Tujuan Pembelajaran Psikomotor

Hasil ketuntasan penilaian psikomotor menunjukkan bahwa pada pretest adalah $0 \%$ hal ini menunjukkan bahwa tidak ada satupun siswa yang dapat menuntaskan tujuan pembelajaran psikomotor. Pada umumnya siswa pernah menggunakan mikroskop namun siswa umumnya tidak diajarkan cara penggunaan mikroskop secara runut dan teratur, namun setelah dilakukan pembelajaran dengan model pembelajaran langsung, pada saat posttest seluruh siswa dapat menuntaskan tujuan pembelajaran psikomotor.

4) Tujuan Pembelajaran Afektif

Rata-rata skor yang diperoleh dalam perilaku berkarakter peduli adalah 3,56 sedangkan skor yang diperoleh dari perilaku karakter tanggung jawab adalah 3,57 .

Untuk tujuan pembelajaran afektif dalam hal keterampilan sosial, skor yang diperoleh dari keterampilan sosial berkomunikasi adalah 3,89 dan keterampilan sosial bertanggung jawab dengan skor rata-rata 3,50. Sebagaimana tujuan pembelajaran afektif dalam hal perilaku berkarakter, dalam hal tujuan pembelajaran afektif mengenai keterampilan sosial juga menunjukkan ketercapaian tujuan dengan kategori yang memuaskan. Sebagaimana yang diungkapkan oleh Carin (1993) bahwa salah satu komponen yang harus dikuasai siswa dalam belajar biologi adalah sikap ilmiah, baik karakter, maupun keterampilan sosialya.

\section{b. Ketuntasan Individual dan Ketuntasan Klasikal \\ 1) Penilaian Produk}

Pada Pretest tidak ada satupun siswa yang tuntas. Berbeda dengan nilai Postets, terdapat 3 siswa yang tidak mencapai nilai KKM. Ketidaktuntasan siswa ini diperkirakan karena beberapa hal, diantaranya adalah tingkat kemampuan kognitif siswa yang berada pada kriteria rendah, sebagaimana yang diutarakan Hasanah (2012) bahwa tingkat kemampuan kognitif siswa yang berada pada criteria rendah dapat menyebabkan siswa tidak dapat memenuhi standar ketuntasan minimal yang ditetapkan.

Adanya peningkatan nilai yang diperoleh pada saat Pretest dan Posttest tak lepas dari pembelajaran dengan menggunakan perangkat pembelajaran yang dikembangkan yang berorientasi pada Keterampilan Proses Sains sehingga siswa dapat memahami teori dan konsep yang diajarkan. Anglo (2002) juga menyatakan bahwa pengalaman siswa sekolah dalam pembelajaran terbimbing seharusnya melibatkan pengalaman yang meningkatkan keterampilan proses karena keterampilan tersebut sangat penting untuk pengembangan pemahaman siswa yang utuh dan berhasil terhadap konsep dan hukum sains. Hal ini didukung oleh pernyataan Funk (1985 dalam Dimyati dan Mudjiono 2002) bahwa dengan menggunakan keterampilan proses untuk mengajar sains atau ilmu pengetahuan lain dapat membuat siswa belajar proses dan produk sekaligus.

2) Penilaian Proses

Dari hasil penelitian untuk ketuntasan individual dalam tujuan pembelajaran proses diketahui bahwa pada ketuntasan siswa pada Lembar Penilaian Proses 1 dalam Pretest terdapat 2 dari 35 siswa yang sudah tuntas. Nilai Posttets semua siswa dinyatakan tuntas. Adanya siswa yang tidak tuntas pada Pretest dikarenakan siswa belum dapat menggambarkan struktur jamur makroskopis seperti yang diharapkan, khususnya dalam detail penggambaran dan tidak lengkapnya pemberian nama bagian jamur makroskopis sebagaiaman yang telah dimodelkan oleh dengan model pembelajaran langsung pada pertemuan 1 . Hal ini sesuai dengan Nwagba (2011) yang menyatakan bahwa metode pengajaran dengan memberikan instruksi kepada siswa akan membantu siswa dalam mencapai keterampilan proses sains lebih baik. 
Hasil ketuntasan siswa pada Lembar Penilaian Proses 2 menunjukkan bahwa pada Pretest tidak ada satupun siswa yang dapat menuntaskan, namun pada Posttest 2 jumlah siswa yang tuntas mencapai $88,57 \%$ dengan 4 dari 35 siswa yang tidak tuntas.

Adanya peningkatan ketuntasan pada Pretest dan Posttest ini tak lepas dari pembelajaran yang sesuai dengan RPP dan Perangkat Pembelajaran yang berorientasi pada Keterampilan Proses Sains (KPS). Sebagaimana yang diungkapkan Tsaniyah (2011) bahwa penguasaan keterampilan proses siswa pada uji awal rendah karena siswa belum memperoleh kesempatan maksimal dalam belajar dan berlatih keterampilan proses sains. Sama halnya hasil penelitian Aktamis dan Ergin (2008) yang menunjukkan bahwa salah satu pengaruh pendidikan keterampilan proses adalah dapat meningkatkan pencapaian akademik atau hasil belajar yang cukup berarti atau signifikan.

3) Penilaian Psikomotor

Hasil ketuntasan penilaian psikomotor menunjukkan bahwa pada pretest tidak ada satupun siswa yang mendapatkan nilai di atas 75 atau dengan kata lain tidak ada siswa yang dapat menuntaskan tujuan pembelajaran psikomotor namun setelah dilakukan pembelajaran dengan model pembelajaran langsung, pada saat posttest siswa dapat menuntaskan tujuan pembelajaran psikomotor dengan rata-rata nilai ketuntasan siswa $\geq 75$ dan siswa dapat menggunakan mikroskop sesuai dengan prosedur dan ada. Hal ini menunjukkan bahwa model pembelajaran langsung sesuai untuk mengajarkan suatu keterampilan prosedural. Keterampilan proses sains melibatkan keterampilan intelektual, keterampilan psikomotor yang terasosiasi, dan keterampilan afektif yang berhubungan dengan pembelajaran semua aspek sains (Sheeba, 2013).

\section{Respon Siswa}

Angket Respon Siswa yang diberikan kepada siswa setelah akhir proses pembelajaran. Data yang diperoleh adalah sebagaimana ditunjukkan di bawah ini:

Tabel 1. Respon Siswa

\begin{tabular}{|l|l|c|c|}
\hline No. & Pertanyaan & \multicolumn{2}{|c|}{$\begin{array}{l}\text { Persentase } \\
\text { Penilaian (\%) }\end{array}$} \\
\hline $\begin{array}{l}\text { Bagaimana pendapat kalian } \\
\text { terhadap komponen berikut ini ? }\end{array}$ & Suka & $\begin{array}{l}\text { Tidak } \\
\text { Suka }\end{array}$ \\
\hline 1 & materi/ isi pelajaran & 100 & 0 \\
\hline 2 & buku siswa & 94 & 6 \\
\hline 3 & $\begin{array}{l}\text { lembar kegiatan siswa } \\
\text { (LKS) }\end{array}$ & 91 & 9 \\
\hline 4 & media pembelajaran & 97 & 3 \\
\hline 5 & kegiatan pembelajaran & 97 & 3 \\
\hline 6 & tes hasil belajar & 80 & 20 \\
\hline \multicolumn{2}{|l|}{ Rata -Rata Skor } & 93 & 7 \\
\hline
\end{tabular}

Model Pembelajaran Pemaknaan pada Materi Sistem

\footnotetext{
Organisasi Kehidupan untuk...
}

\begin{tabular}{|c|c|c|c|}
\hline No. & Pertanyaan & \multicolumn{2}{|c|}{\begin{tabular}{|l|} 
Persentase \\
Penilaian $(\%)$
\end{tabular}} \\
\hline \multicolumn{2}{|c|}{$\begin{array}{l}\text { Apakah kalian merasa baru } \\
\text { terhadap komponen-komponen } \\
\text { berikut ini ? }\end{array}$} & Baru & \begin{tabular}{|l} 
Tidak \\
Baru
\end{tabular} \\
\hline 1 & materi/ isi pelajaran & 89 & 11 \\
\hline 2 & buku siswa & 89 & 11 \\
\hline 3 & $\begin{array}{|lll|}\text { lembar } & \text { kegiatan } & \text { siswa } \\
(\text { LKS }) & & \\
\end{array}$ & 86 & 14 \\
\hline 4 & media pembelajaran & 83 & 17 \\
\hline 5 & kegiatan pembelajaran & 89 & 11 \\
\hline 6 & tes hasil belajar & 83 & 17 \\
\hline \multicolumn{2}{|c|}{ Rata -Rata Skor } & 86 & 14 \\
\hline \multicolumn{2}{|c|}{$\begin{array}{l}\text { Apakah kalian dengan mudah } \\
\text { dapat memahami terhadap } \\
\text { komponen-komponen berikut ini } \\
\text { ? }\end{array}$} & Mudah & Sulit \\
\hline 1 & materi/ isi pelajaran & 80 & 20 \\
\hline 2 & buku siswa & 86 & 14 \\
\hline 3 & $\begin{array}{lll}\begin{array}{l}\text { lembar } \\
\text { (LKS) }\end{array} & \text { kegiatan } & \text { siswa } \\
\end{array}$ & 83 & 17 \\
\hline 4 & media pembelajaran & 94 & 6 \\
\hline 5 & kegiatan pembelajaran & 94 & 6 \\
\hline 6 & tes hasil belajar & 54 & 46 \\
\hline \multicolumn{2}{|c|}{ Rata -Rata Skor } & 82 & 18 \\
\hline \multicolumn{2}{|c|}{$\begin{array}{l}\text { Bagaimanakah penilaianmu } \\
\text { tentang keterampilan proses } \\
\text { berikut ini: }\end{array}$} & Baru & $\begin{array}{l}\text { Tidak } \\
\text { Baru }\end{array}$ \\
\hline 1 & Menggambar & 83 & 17 \\
\hline 2 & merumuskan masalah & 77 & 31 \\
\hline 3 & merumuskan hipotesis & 80 & 29 \\
\hline 4 & mengidentifikasi variabel & 69 & 31 \\
\hline 5 & melaksanakan eksperimen & 80 & 20 \\
\hline 6 & menginterpretasikan data & 74 & 26 \\
\hline 7 & menganalisis data & 71 & 29 \\
\hline 8 & membuat kesimpulan & 63 & 37 \\
\hline \multirow{2}{*}{\multicolumn{2}{|c|}{ Rata -Rata Skor }} & 75 & 28 \\
\hline & & Suka & $\begin{array}{l}\text { Tidak } \\
\text { Suka }\end{array}$ \\
\hline \multicolumn{2}{|c|}{$\begin{array}{l}\text { Bagaimana pendapat kalian } \\
\text { terhadap pembelajaran ini? }\end{array}$} & 100 & 0 \\
\hline
\end{tabular}

Hasil angket respon siswa, 93\% siswa menyatakan bahwa mereka menyukai komponen perangkat pembelajaran yang dikembangkan. Hal ini disebabkan karena perangkat pembelajaran yang dikembangkan berbeda dengan perangkat pembelajaran yang pernah mereka terima sebelumnya sehingga menimbulkan rasa tertarik dalam diri siswa. Ketertarikan siswa ini diharapkan dapat memudahkan dan memotivasi siswa dalam memahami konsep yang diajarkan sehingga dapat berpengaruh pada pencapaian hasil belajar siswa yang maksimal, sesuai dengan pernyataan Pintrich dan Schunk (1996 dalam Mathedu, 2009) yang menyatakan 
bahwa tertarik atau minat merupakan aspek penting dari motivasi yang mempengaruhi perhatian, belajar, berpikir, dan berprestasi.

Respon siswa menunjukkan bahwa $86 \%$ siswa menyatakan bahwa komponen perangkat pembelajaran yang dikembangkan adalah hal yang baru. Dalam hal pemahaman, respon siswa menunjukkan bahwa $85 \%$ siswa menyatakan bahwa perangkat pembelajaran yang dikembangkan mudah untuk dipahami.

Sebanyak $75 \%$ siswa menyatakan bahwa keterampilan proses adalah hal baru bagi mereka. Namun ketertarikan siswa dalam komponen perangkat pembelajaran yang dikembangkan membuat siswa lebih mudah untuk memahami perangkat pembelajaran yang dikembangkan. $100 \%$ siswa menyatakan bahwa mereka menyukai pembelajaran dengan menggunakan perangkat pembelajaran yang dikembangkan. Menurut peneliti, kesukaan atau kesenangan siswa dalam pembelajaran dengan menggunakan perangkat pembelajaran yang dikembangkan dengan pendekatan Keterampilan Proses Sains memotivasi siswa dalam belajar dan memudahkan pemahaman siswa dalam memahami konsep dan terori yang diajarkan. Sebagaimana yang diungkapkan oleh Schein (1991 dalam Dimyati dan Mudjiono: 2002) bahwa dengan belajar yang bermotivasi, siswa dapat memperoleh hasil belajar yang tinggi.

\section{Keterlaksanaan Perangkat Pembelajaran}

Keterlaksanaan perangkat pembelajaran yang dikembangkan, diamati oleh 2 orang dalam setiap pertemuan. Adapaun hasil yang diperoleh adalah sebagai berikut:

Tabel 2. Keterlaksanaan RPP

\begin{tabular}{|c|l|c|c|c|}
\hline \multirow{2}{*}{ No. } & \multirow{2}{*}{$\begin{array}{c}\text { Kegiatan } \\
\text { Pembelajaran }\end{array}$} & \multicolumn{3}{|c|}{ Skor } \\
\cline { 3 - 5 } & RPP 1 & RPP 2 & RPP 3 \\
\hline 1 & Pendahuluan & 4,33 & 4,67 & 4,83 \\
\hline 2 & Inti & 4,00 & 3,90 & 4,19 \\
\hline 3 & Penutup & 4,00 & 5,00 & 4,00 \\
\hline \multicolumn{2}{|l|}{ Rata-rata } & 4,11 & 4,52 & 4,34 \\
\hline Keterlaksanaan (\%) & 100 & 100 & 100 \\
\hline \multicolumn{2}{|l|}{ Reliabilitas Instrumen (\%) } & 90,48 & 90,91 & 91,67 \\
\hline
\end{tabular}

Hasil pengamatan keterlaksanaan seluruh RPP memiliki persentasi keterlaksanaan RPP sebesar $100 \%$ hal ini menujukkan bahwa secara umum pelaksanaan pembelajaran terlaksana dengan sangat baik. Hal ini dikarenakan proses pembelajaran yang dilakukan mengikuti tahap sesuai yang tertulis pada masingmasing RPP sesuai dengan model pembelajaran yang digunakan.

Terlaksananya tiap sintaks yang dituliskan juga berpengaruh besar dalam pemahaman siswa dalam mencapai tujuan pembelajaran, baik tujuan pembelajaran produk, proses, maupun afektif.
Model pembelajaran langsung pada pertemuan 1 untuk mengajarkan keterampilan psikomotor dalam penggunaan mikroskop dan keterampilan proses menggambar ilmiah dan pada pertemuan 2 untuk mengajarkan kepada siswa keterampilan proses sains terpadu. Hal ini sesuai dengan penelitian Tinenti (2009) yang menyakan bahwa penerapan keterampilan proses melalui model pengajaran langsung dapat meningkatkan penugasan keterampilan proses dan hasil belajar produk, proses, dan psikomotorik.

Pada pertemuan ke 3 yang mengajarkan keterampilan proses sosial, presentasi, digunakan model pembelajaran kooperatif. Dengan model pembelajaran kooperatif siswa diharapkan dapat bersosialisasi dengan temannya selain untuk melatih keterampilan afektif karakter dan sosial mereka, juga untuk meningkatkan pemahaman mereka dalam keterampilan proses sains yang diajarkan. Hal ini juga dinyatakan oleh Igboegwu, (2001) dalam penelitiannya, bahwa penelitian terbaru menunjukkan bahwa strategi pembelajaran kooperatif meningkatkan pemahaman keterampilan proses dalam pembelajaran kimia pada siswa dengan pemahaman yang berbeda-beda daripada metode demonstrasi.

\section{Aktivitas Siswa}

Aktivitas siswa selama mengikuti kegiatan pembelajaran memperoleh hasil sebagaimana yang ditunjukkan di bawah ini:

Tabel 3. Hasil Pengamatan Aktivitas Siswa pada Pertemuan 1

\begin{tabular}{|l|l|c|c|}
\hline No. & Aktivitas Siswa & $\begin{array}{l}\text { Aktivitas } \\
\text { Siswa (\%) }\end{array}$ & $\begin{array}{l}\text { Reliabili } \\
\text { tas (\%) }\end{array}$ \\
\hline 1 & $\begin{array}{l}\text { Mendengarkan } \\
\text { ceramah/penjelasan } \\
\text { guru. }\end{array}$ & 24.24 & 98.98 \\
\hline 2 & $\begin{array}{l}\text { Mengamati struktur } \\
\text { tubuh jamur. }\end{array}$ & 33.15 & 99.25 \\
\hline 3 & $\begin{array}{l}\text { Berdiskusi dengan } \\
\text { kelompok. }\end{array}$ & 27.58 & 98.21 \\
\hline 4 & Bertanya pada guru. & 6.06 & 97.96 \\
\hline 5 & $\begin{array}{l}\text { Mengkomunikasikan } \\
\text { Informasi. }\end{array}$ & 6.00 & 96.91 \\
\hline 6 & Perilaku tidak relevan. & 2.97 & 83.33 \\
\hline \multicolumn{2}{|l|}{ Rata-rata Reliabilitas (\%) } & \multicolumn{2}{|c|}{95,77} \\
\hline
\end{tabular}

Tabel 4. Hasil Pengamatan Aktivitas Siswa pada Pertemuan 2

\begin{tabular}{|l|l|c|c|}
\hline No. & Aktivitas Siswa & $\begin{array}{l}\text { Aktivitas } \\
\text { Siswa (\%) }\end{array}$ & $\begin{array}{c}\text { Reliabil } \\
\text { itas (\%) }\end{array}$ \\
\hline 1 & $\begin{array}{l}\text { Mendengarkan } \\
\text { ceramah/penjelasan } \\
\text { guru. }\end{array}$ & 33.42 & 99.39 \\
\hline 2 & Mendiskusikan tugas. & 10.67 & 98.85 \\
\hline 3 & Berdiskusi dengan & 39.35 & 98.75 \\
\hline
\end{tabular}




\begin{tabular}{|l|l|c|c|}
\hline \hline No. & Aktivitas Siswa & $\begin{array}{l}\text { Aktivitas } \\
\text { Siswa (\%) }\end{array}$ & $\begin{array}{l}\text { Reliabil } \\
\text { itas (\%) }\end{array}$ \\
\hline & kelompok. & & 99.24 \\
\hline 4 & $\begin{array}{l}\text { Melakukan } \\
\text { eksperimen. }\end{array}$ & 5.36 & 97.30 \\
\hline 5 & Bertanya pada guru. & 3.03 & 98.65 \\
\hline 6 & $\begin{array}{l}\text { Mengkomunikasikan } \\
\text { Informasi. }\end{array}$ & 6.05 & 96.15 \\
\hline 7 & $\begin{array}{l}\text { Perilaku tidak } \\
\text { relevan. }\end{array}$ & 2.13 & \multicolumn{2}{|c|}{98,33} \\
\hline Rata-rata Reliabilitas (\%) & \multicolumn{2}{|c|}{} \\
\hline
\end{tabular}

diajarkan dan harus dilatihkan pada siswa dengan pemodelan sesuai dengan model pembelajaran langsung, karenanya guru meminta siswa untuk berkoordinasi dalam kelompoknya dengan lebih efisien untuk mempersingkat waktu.

b. Siswa

Siswa belum terbiasa dengan pembelajaran dengan menggunakan pendekatan Keterampilan Proses Sains sehingga dengan menggunakan model pembelajaran langsung. Sebagaimana Nwagba (2011) yang menyatakan bahwa metode pengajaran dengan memberikan instruksi kepada siswa akan membantu

Tabel 5. Hasil Pengamatan Aktivitas Siswa pada Pertemuan 3

\begin{tabular}{|c|c|c|c|}
\hline No. & Aktivitas Siswa & $\begin{array}{l}\text { Aktivitas } \\
\text { Siswa (\%) }\end{array}$ & $\begin{array}{l}\text { Reliabil } \\
\text { itas (\%) }\end{array}$ \\
\hline 1 & $\begin{array}{l}\text { Mendengarkan } \\
\text { ceramah/penjelasan } \\
\text { guru. }\end{array}$ & 21.94 & 99.63 \\
\hline 2 & Mendiskusikan tugas. & 28.79 & 98.02 \\
\hline 3 & $\begin{array}{l}\text { Melakukan searching } \\
\text { internet. }\end{array}$ & 31.16 & 98.43 \\
\hline 4 & Bertanya pada guru. & 4.49 & 98.18 \\
\hline 5 & $\begin{array}{l}\text { Mengkomunikasikan } \\
\text { Informasi. }\end{array}$ & 10.36 & 97.64 \\
\hline 6 & $\begin{array}{l}\text { Perilaku tidak } \\
\text { relevan. }\end{array}$ & 3.26 & 90.00 \\
\hline \multicolumn{2}{|c|}{ Rata-rata Reliabilitas (\%) } & \multicolumn{2}{|c|}{96,98} \\
\hline
\end{tabular}

Pada pertemuan 1 aktivitas siswa yang paling dominan adalah mengamati struktur tubuh jamur. Pada pertemuan 2 aktivitas yang paling dominan adalah berdiskusi dengan kelompok. Pada pertemuan 3 aktivitas siswa yang paling dominan adalah melakukan searching di internet. Aktivitas siswa akan mempengaruhi berlangsungnya proses pembelajaran dan hasil belajar siswa. Ismail (2010) menyatakan bahwa keterampilan proses sains dan keterampilan berpikir merupakan suatu kesatuan. Diharapkan, bahwa dengan pembelajaran sains secara aktif, siswa dapat mencapai baik keterampilan proses sains dan juga mengembangkan keterampilan berpikir mereka.

\section{Hambatan Lapangan}

Hasil penelitian mengenai hambatan yang muncul selama kegiatan belajar mengajar berlangsung, secara umum dapat dikatakan bahwa beberapa hambatan yang muncul dapat diatasi. Adapun hambatan-hambatan tersebut akan dikemukakan berikut ini.

a. Waktu

Pada saat pertemuan kedua yang mengajarkan Keterampilan Proses Sains terpadu memerlukan waktu lebih lama dari yang diperkirakan oleh peneliti. Hal ini dikarenakan banyaknya keterampilan sains yang siswa dalam mencapai keterampilan proses sains lebih baik.

c. Pembendaharaan Kata Bahasa Inggris

Pembendaharaan kata-kata dalam bahasa Inggris siswa dapat dikatakan terbatas, sehingga guru menyarankan agar siswa membaca dulu perangkat pembelajaran yang mereka terima serta siswa diminta untuk menggunakan kamus.

\section{KESIMPULAN}

\section{A. Simpulan}

Berdasarkan analisis dan diskusi hasil penelitian, dapat disimpulkan bahwa:

1. Hasil validasi perangkat pembelajaran biologi berbahasa Inggris dengan pendekatan keterampilan proses pada materi Kingdom Jamur yang dikembangkan oleh peneliti meliputi silabus, RPP, buku siswa, LKS, media pembelajaran, dan lembar penilaian menunjukkan kategori sangat layak/valid.

2. Efektivitas perangkat pembelajaran yang dikembangkan oleh peneliti dapat dilihat dari:

a. Hasil Belajar Siswa

Hasil belajar siswa setelah mengikuti pembelajaran dapat meningkatkan pemahaman siswa dan membantu siswa untuk dapat menuntaskan tujuan pembelajaran.

b. Respon Siswa

Respon siswa menunjukkan bahwa sebagian besar siswa menyukai komponen perangkat pembelajaran yang dikembangkan. Respon siswa yang positif ini menunjukkan bahwa perangkat pembelajaran yang dikembangkan dapat memotivasi siswa dalam belajar dan memudahkan pemahaman siswa dalam memahami konsep dan teori yang diajarkan.

c. Keterlaksanaan RPP

Keterlaksanaan perangkat pembelajaran dari ketiga RPP yang telah diaplikasikan di kelas adalah $100 \%$.

d. Aktivitas Siswa

Aktivitas siswa yang paling dominan secara berurutan untuk 3 pertemuan adalah mengamati 
struktur tubuh jamur, berdiskusi kelompok dan melakukan eksperimen, dan mendiskusikan tugas.

e. Hambatan Lapangan

Hambatan yang terjadi di lapangan adalah waktu yang dibutuhkan, ketidakbiasaan siswa dalam mengikuti pembelajaran dengan menggunakan keterampilan proses sains, dan kurangnya pembendaharaan kata bahasa Inggris yang dimiliki oleh siswa. Secara umum, beberapa solusi telah ditemukan untuk mengatasi hambatan yang ada, sehingga hambatan-hambatan tersebut tidak menjadi hambatan yang berarti dalam proses pembelajaran.

\section{B. Saran}

Berdasarkan simpulan, peneliti menyarankan:

1. Proses pembelajaran dengan menggunakan perangkat pembelajaran biologi berbahasa Inggris dengan pendekatan keterampilan proses pada materi Kingdom Jamur membutuhkan persiapan dan pengelolaan waktu yang baik agar kegiatan pembelajaran dapat berlangsung sesuai dengan RPP.

2. Dilakukan penelitian lanjutan untuk pengembangan perangkat pembelajaran biologi dengan menggunakan pendekatan keterampilan proses baik keterampilan proses pada materi biologi yang lain.

3. Setiap perangkat pembelajaran model maupun pendekatan apapun hendaknya meyisipkan nilai karakter untuk menanamkan karakter yang baik pada anak didik.

\section{REFERENSI}

Aktamis, H., dan Ö. Ergin. (2008). "The Effect of Science Process Skill Education on Students Scientific Creativity". Science Attitude, and Academic Achievement. Asia-Pasific Forum on Science Learning and Teaching. Turki. Vol. 9 Issue 1, pp. 1-21.

Anglo, M. (2002). "Mastery of Science Process Skills and Their Effective Use in the Teaching of Science: An Educology of Science Education in the Nigerian Context". International Journal of Educology. Vol 16, No. 1, pp. 11-30

Carin, A. (1993). Teaching Modern Science. Sixth Edition. New York: Merril, An Imprint of Mc. Millan Publishing Company.

Dimyati, dan Mudjiono. (2002). Belajar dan Pembelajaran. Jakarta: PT. Rineka Cipta.

Hasanah, R. (2012). Pengembangan Perangkat Pembelajaran Biologi Berorientasi Keterampilan Proses pada Materi Metabolisme
Karbohidrat di Kelas XII SMA/MA. Program Studi Pendidikan Sains, Program Pasca Sarjana Unesa. Tesis tidak dipublikasikan.

Ismail, Z. H. dan Ismail J. (2010). "Relationship between Science Process Skills and Logical Thinking Abilities of Malaysian Students". Journal of Science and Mathematics Education in S. E. Asia. Vol. XXIV, No. 2

Mathedu. (2009). Pengertian Minat. Artikel. (online). Tersedia: $\quad$ http://matheduunila.blogspot.com/2009/10/pengertianminat.ht $\underline{\mathrm{ml}}$ (diakses tanggal 24 Juli 2014)

N., Iqoegwu dan N. Egbutu R. (2011). "Effects of CoOperative Learning Strategy and Demonstration Method on Acquisition of Science Process Skills by Chemistry Students of Different Levels of Scientific Literacy". Journal of Research of Development. Vol. 3, No. 1.

Nur, M. (2000). Buku Panduan Keterampilan Proses dan Hakikat Sains. Surabaya : Unesa University Press.

Nwagba C. dan Chukelu, U. C. (2011). "Effects of Biology Practical Activities on Students' Process Skill Acquisition". Journal of Science Teachers Association of Nigeria.

Sheeba, M. N. (2013). An Anatomy of Science Process Skills In The Light Of The Challenges to Realize Science Instruction Leading To Global Excellence in Education. Educationia Confab. ISSN: 2320-009X. Volume 2 No. 4. Tersedia online

http://www.confabjournals.com/confabjournals/i mages/6520138281213.pdf

Thiagarajaan, S., Semmel, D. S., \& Semmel, M. I. (1974). Instructional Development for Training Teacher of Exceptional Children a Sourcebook. Bloomington: Center for innovation on teaching the handicapped.

Tsaniyah, A. (2011). Pengembangan Perangkat Pembelajaran IPS (Fisika) SMP dengan Menggunakan Metode Fun Games dalam Model Pembelajaran Kuantum. Program Studi Pendidikan Sains, Program Pasca Sarjana Unesa. Tesis tidak dipublikasikan.

Tinenti, Y. R. (2009). Pengembangan Perangkat Model Pengajaran Langsung dan Pendekatan Keterampilan Proses yang Terintegrasi dalam Model Pembelajaran Berbasis Proyek. Program Studi Pendidikan Sains. Program Pasca Sarjana Unesa. Tesis tidak dipublikasikan. 